\title{
Comparison of Industry Openness in Positive and Negative List Management Mode*
}

\author{
Weitao Liu \\ Jinan University \\ Guangzhou, China 510632
}

Xianghe Liu**

Guangdong University of Foreign Studies

Guangzhou, China 510006

**Corresponding Author

\author{
Qi Gao \\ Jiamusi City Center Branch \\ People's Bank of China \\ Jiamusi, China 154002 \\ Yuqiang Cao \\ Jinan University \\ Guangzhou, China 510632
}

\begin{abstract}
Since the establishment of the Shanghai Free Trade Zone in 2013, China started exploring on the negative list management mode. This paper first carries out numerical comparison analysis of two foreign investment management modes of current positive and negative list by using character recognition. Research found that there is difference between the two modes, and restrictions on negative list are less in manufacturing and tertiary industry. Finally, this paper will provide relevant suggestions of problems of current negative list.
\end{abstract}

Keywords-positive list; negative list; industry relative openness; industry restrictions

\section{INTRODUCTION}

It has been the key point of attracting direct investment from foreign business for our government to implement the opening up strategy. Since China joined the WTO in 2002, disbursement of foreign capital has increased from $\$ 53.505$ billion in 2003 to $\$ 126$ billion in 2016. The more obvious of a country's policy-oriented role, the more effective to guide the inflow of foreign capital so that to achieve the goal of promoting the economic growth. But the inflow of the foreign capital will not only bring positive effect, but also possible to bring the negative impact, especially for the industry in disadvantage situation or related to national economy and people's livelihood in developing country. Thus it is more necessary for a country to conduct restrictions and guidance on foreign capital in some degree when formulating corresponding industrial policies.

Generally speaking, foreign investment access system includes industry policy at the entity level and approval system at the procedure level. China has respectively enacted relevant

*Fund programs: Guangdong philosophy and social science planning project (Program number: GD12CGL05); Guangdong philosophy and social science planning project (Program number: 2017GZZK34); University-level teaching reform project of Guangdong University of Foreign Studies (Program number: GWJY2015029); Blue book project 2017 of International economic and trade research center of Guangdong University of Foreign Studies (project number: 2017L-04)

CLC No.: F741.2 Document Code: A regulation of guiding foreign capital inflow for ten times in 1983, 1987, 1995, 2002, 2004, 2007, 2011, 2015, 2017, gradually evolved from initial "allowed" foreign capital inflow into "attracting" foreign capital inflow, and the management of foreign investment projects also changed from initial "investment attraction" to "investment selection. The foreign investment access system in the positive list management mode has played a big role in the process of gradual transformation. For China, which is in the process of economic transformation, the continuous evolution of policies is particularly important for the choice of foreign-invested enterprises and development of the country. With the establishment of Shanghai Free Trade Zone in 2003, the negative list management mode has been started in China, and it must be a major reform direction to guide the foreign investment of pre-establishment national treatment plus negative list management mode because of the BIT (Bilateral Investment Treaty) negotiation and successive establishment of Free Trade Zones of Guangdong, Fujian and Tianjin. Comparing to the positive list management mode, negative list of management mode is more transparent in the foreign investment access aspect, enhancing the stable expectation of foreign investment, which plays a positive role in attracting foreign investment.

From the perspective of industry policy, this paper will carry out comparison analysis of character recognition, assignment quantization and industry share on both positive and negative list management mode. This paper first carries out numerical comparison analysis of two foreign investment management modes, which is of theoretical and practical significance to the following research of negative list and promotion of negative list management mode in China.

\section{LITERARY REVIEW}

Theoretically, it is commonly considered that removing or reducing barriers to foreign investment, and decreasing the cost of foreign capital entry will attract more foreign investment so that to improve national welfare effect. Douglas 
(1998) has pointed out that the openness of foreign market access would promote the formation of a global unified market, and the key lies on the innovation of foreign investment management mode. Moreover, normalization of market access mechanisms in various countries will further bring a unified trading environment (Kawamoto, 2001). Zhang Luqing (2009) and Busse (2010) have verified that after signing BIT, developing country will play an effective role in weakening the domestic system of host country, which will be beneficial to the introduction of foreign capital in the host country. Hallward(2003) and Tobin (2011) have empirical tested the economic effect of signing BIT on developing country, which proves that it is beneficial for developing country to attract foreign investment by signing BIT, and the guarantee of state institution will better promote the role of BIT. Of course, some scholars also questioned the above research (Yackee, 2010; Allee, 2011; Berger, 2013). Shao Haiyan, etc. (2016) considers that the difference of current research is mainly due to the lack of careful analysis of impact mechanism of the policy, and research of developing country.

With the establishment of Shanghai Free Trade Zone in 2013, and successive establishment of Free Trade Zone of Guangdong, Fujian, Tianjin, the negative list management mode gradually enters the domestic researchers' vision, but there is little relevant research. Sun Yuanxin (2014a, 2014b) and Pang Mingchuan (2014) have analyzed the special management measures for foreign investment in Free Trade Zone (that is negative list) enacted in 2013 and 2014, pointing out the innovation compared to the positive list management mode, and the deficiency of current negative list management mode. Wang Jing (2014) has pointed out that the negative list management mode will greatly reduce the registration procedure for foreign-invested enterprises, improve the foreign investment introduction efficiency, and improve foreign investment opening up due to improvement of management system. The negative list management mode will reduce the rent-seeking space in government departments. Certainly, some scholars have also discussed the shortcomings of the negative list. Gong Baihua (2013) has pointed out that compared to positive list management mode, there is no real breakthrough in the negative list management mode, more of which is the change of industry and classification arrangements. Also, there is no substantive change in the areas of openness (Hu Jiaxiang, 2014). Wu Fang (2014) thinks the actions of negative list management mode are complex; the transparency of it is not enough, and not in line with international standards in industry classification. Of course, currently, China is still in the explosion stage in the formulation of negative list, which lacks of legislation, and with a narrow radiation scope (Yang Haikun, 2014; Wang Xinkui, 2014).

Though current literature have compared domestic and foreign mode of foreign investment, and discussed the current negative list management mode in Free Trade Zone in China (Sun Yuanxin, (2014c; Zhang Xiaoming, Zhang Jianhua, 2015), but there is little quantitative research on industry openness. Deng Juanjuan (2016) has calculated the openness of Chinese logistics by means of hypothetical statistics from the perceptive of positive and negative list, but limited to logistic industry. The purpose and value of this paper is to compare the degree of relative openness and restrictions in the overall industry of the two foreign management modes so that to fill the gap in the current academic research and make corresponding suggestions on the current negative list management mode.

\section{BRIEF INTRODUCTION OF THE TWO METHODS OF CAlCulating Foreign InVESTMENT MANAGEMENT ModE}

The data cited in this paper is from the six-year Catalogue of Industries for Guiding Foreign Investment in 2002, 2004, 2007, 2011, 2015, 2017 and five-year special management measures for foreign investment in Free Trade Zone (that is negative list) in 2013, 2014, 2015, 2016, 2017, comparing and analyzing the positive and negative list management mode by two kinds of measurement methods. Learning from Yin Huafang's (2006) method, we quantify the text in the catalogue and negative management list. The specific approach is: first, count the three-digit industry entries that "encouragement", "restrictions", "prohibition" in the negative management mode. Then, add the numerical value of the three-digit industry to a large category. In the process of specific calculation, we found that the Catalogue of Industries for Guiding Foreign Investment has clearly encouraged industry, restricted industry and prohibited industry. However, in the special management actions for foreign investment in Free Trade Zone, we need to classify them according to the given specific measures, that are where there are definite restrictions and prohibitions, we shall respectively classify them as restriction and prohibition, such as: limit investment in butadiene rubber (except for HCBR), SBR emulsion polymerization, and SBS production; prohibit investment in open lead (the acid mist is directly exclusive) acid battery, mercury-containing silver oxide battery, mercury-containing alkaline zinc-manganese battery, paste zinc manganese battery, nickel-cadmium cell manufacturing. Meanwhile, in case of a joint venture or a certain requirement for the amount of contribution, we shall classify it as restriction, such as: investment in design of deepwater (over $3000 \mathrm{~m}$ ) marine engineering equipment shall be joint venture and cooperated. Of course, as for the positive list, we shall do the same as this, which means we shall classify the items limited investment or territory as restriction. Such as: development and application of new technologies for oil exploration and development like geophysical prospecting, drill, well-logging, mudlogging, borehole operation and etc. (limit to joint venture and cooperation). Later on, we assign $3,2,1$ respectively to "encouragement", "limitation" and "prohibition", in order to avoid the absolute difference among the values of different years, we divide the specific openness value of each industry by national openness index so that to obtain relative openness index of each industry.

In order to avoid the subjectivity of the assignment method, we also comparing and analyzing in a second method, that is, the number of restrictions and prohibitions entries accounts for the total number of the three-digit subdivision industries to indicate the degree of restriction of each industry. Such as: the total restrictions and prohibitions are 6 in 2007 in agriculture, forestry, animal husbandry and fishery, with total 18 three- 
digit subdivision industries, thus the degree of restrictions is 0.0354. In the specific calculation process, because the time span is from 2002 to 2015 , during which national industry standards have been adjusted accordingly, we have unified adjustment to be based on GBT 4754-2002 in order for easy calculation.

\section{RESUlT AND ANALYSIS OF MEASUREMENT}

\section{A. Industry Relative Index Measurement}

According to the measurement method provided in the above, we have calculated the degree of openness and restriction in both positive and negative list management modes by two methods, among which, the industry relative openness index under the positive list management mode is as shown in "Table I".

TABLE I. RELATIVE OPENNESS INDEX OF POSITIVE LIST

\begin{tabular}{|c|c|c|c|c|c|c|}
\hline & 2002 & 2004 & 2007 & 2011 & 2015 & 2017 \\
\hline Agriculture, forestry, animal husbandry and fishery & 0.0416 & 0.0419 & 0.0354 & 0.0332 & 0.0301 & 0.0345 \\
\hline Mining industry & 0.0489 & 0.0492 & 0.0378 & 0.0364 & 0.0224 & 0.0207 \\
\hline Manufacturing industry & 0.6923 & 0.6827 & 0.7346 & 0.7194 & 0.7252 & 0.7089 \\
\hline Production and supply of electricity, gas and water & 0.0281 & 0.0283 & 0.0205 & 0.0269 & 0.0405 & 0.0439 \\
\hline Construction industry & 0.0031 & 0.0157 & 0.0228 & 0.0182 & 0.0164 & 0.0000 \\
\hline Transportation, warehousing and postal services & 0.0208 & 0.0398 & 0.0260 & 0.0324 & 0.0284 & 0.0499 \\
\hline Information transmission, computer services and software & 0.0343 & 0.0021 & 0.0016 & 0.0016 & 0.0017 & 0.0052 \\
\hline Wholesale and retail trade & 0.0021 & 0.0199 & 0.0142 & 0.0166 & 0.0129 & 0.0146 \\
\hline Hotels and catering services & 0.0198 & 0.0136 & 0.0079 & 0.0079 & 0.0069 & 0.0000 \\
\hline Financial industry & 0.0135 & 0.0094 & 0.0047 & 0.0047 & 0.0207 & 0.0138 \\
\hline Real estate & 0.0073 & 0.0115 & 0.0126 & 0.0198 & 0.0474 & 0.0000 \\
\hline Leasing and business service & 0.0239 & 0.0419 & 0.0394 & 0.0419 & 0.0121 & 0.0163 \\
\hline $\begin{array}{l}\text { Scientific research, technical services and geological } \\
\text { survey }\end{array}$ & 0.0416 & 0.0126 & 0.0126 & 0.0111 & 0.0086 & 0.0508 \\
\hline $\begin{array}{l}\text { Water conservancy, environment and public facilities } \\
\text { management }\end{array}$ & 0.0031 & 0.0063 & 0.0047 & 0.0071 & 0.0069 & 0.0103 \\
\hline Resident and other service & 0.0083 & 0.0063 & 0.0039 & 0.0024 & 0.0198 & 0.0017 \\
\hline Education industry & 0.0021 & 0.0073 & 0.0213 & 0.0206 & 0.0301 & 0.0052 \\
\hline Health, social security and social welfare & 0.0094 & 0.0115 & 0.0354 & 0.0332 & 0.0224 & 0.0069 \\
\hline Culture, sports and entertainment & 0.0416 & 0.0419 & 0.0378 & 0.0364 & 0.0725 & 0.0172 \\
\hline
\end{tabular}

The value in "Table I" is the industry relative openness index calculated by Catalogue of Industries for Guiding Foreign Investment. It can be seen from table 1 that most national industries openness degree has increased, and there is difference among the change in the three industries from the broad categories. The primary industry cannot compete with advanced foreign technologies, but it is related to the national economy and people's livelihood, and its relative openness is decreasing year by year; while among the secondary industries, except for mining industry, the other three industries openness degree has increased. Currently, the "reindustrialization" of the United States and the "industry 4.0 " proposed by Germany both show that developed countries attach importance to the manufacturing industry. On this background, it is more proper policy direction to expand the openness degree of this industry, actively rely on the overflow effectiveness brought by foreign investment, and five play to our own comparative advantages; we are always serious about the openness of the tertiary industry, and it can be seen that except for information transmission, computer services and software, hotels and catering, leasing and business service, scientific research, technical services and geological survey among the tertiary industry, the other industries openness degree has increased. Especially for financial industry, real estate, education, resident service and other service industries, their openness degree in 2015 has increased by 2, 6, 14 and 2.5 times compared with 2002.From the perceptive of policy, manufacturing industry is still the most open one. Till 2015, the openness degree of real estate, culture, sports and entertainment industries is just lower than that of manufacturing industry, and the openness degree of education and real estate industry has increased respectively by 14 times and 6 times than that in 2002, which shall be related to the construction of education in China, besides, the continuous open of real estate may bring the industrial reorganization of real estate. The most open industry in 2007 is transportation, warehousing, postal industry, scientific research, technical services and geological survey, which shows China has begun to publish more policy support in infrastructure construction and innovation development.

The opposite side of positive list is the negative list. In academic area, it is considered that any management restrictions on foreign investment that are not in conformity with the national treatment and most-favored-nation treatment, or the performance requirements, senior management requirements and etc. shall be enumerated. In short, negative list is the "blacklist" in the investment area, any area or industry listed in this "blacklist" shall not be invested or restricted invested by foreign enterprises. The negative list management mode began to be implemented from 2013, 2014 in Shanghai Free Trade Zone; after comparing with international negative list management mode and considering China's actual economic situation, the state decided to implement the same negative list of four Free Trade Zones--Shanghai, Guangdong, Tianjin, Fujian from 2015, and published three negative lists in 2015,2016,2017. Compared with positive list, there is no encouragement item enumerated in negative list, only with restriction items and prohibition items, thus we will refer to the negative list measure of the first 
method as the relative limitation degree, results shown in "Table II".

TABLE II. RELATIVE RESTRICTION INDEX OF NEGATIVE LIST

\begin{tabular}{|c|c|c|c|c|c|}
\hline & 2013 & 2014 & 2015 & 2016 & 2017 \\
\hline Agriculture, forestry, animal husbandry and fishery & 0.0359 & 0.0402 & 0.0490 & 0.0903 & 0.0476 \\
\hline Mining industry & 0.0898 & 0.1044 & 0.0637 & 0.0143 & 0.0544 \\
\hline Manufacturing industry & 0.3323 & 0.3454 & 0.1716 & 0.1273 & 0.1429 \\
\hline Production and supply of electricity, gas and water & 0.0269 & 0.0161 & 0.0294 & 0.0123 & 0.0408 \\
\hline Wholesale and retail trade & 0.0240 & 0.0321 & 0.0000 & 0.0719 & 0.0000 \\
\hline Transportation, warehousing and postal services & 0.0689 & 0.0683 & 0.0294 & 0.0657 & 0.0408 \\
\hline Hotels and catering services & 0.1198 & 0.1125 & 0.1667 & 0.0801 & 0.1156 \\
\hline $\begin{array}{l}\text { Information transmission, software and information } \\
\text { technology services }\end{array}$ & 0.0359 & 0.0482 & 0.0000 & 0.0082 & 0.0000 \\
\hline Financial industry & 0.0299 & 0.0321 & 0.0294 & 0.0411 & 0.0408 \\
\hline Real estate & 0.0210 & 0.0201 & 0.1471 & 0.0739 & 0.1769 \\
\hline Leasing and business service & 0.0749 & 0.0683 & 0.0000 & 0.0041 & 0.0000 \\
\hline Scientific research, technical services & 0.0599 & 0.0241 & 0.0784 & 0.0924 & 0.0544 \\
\hline $\begin{array}{l}\text { Water conservancy, environment and public facilities } \\
\text { management }\end{array}$ & 0.0120 & 0.0161 & 0.0245 & 0.0513 & 0.0340 \\
\hline Resident, repairs and other service & 0.0150 & 0.0201 & 0.0196 & 0.1129 & 0.0136 \\
\hline Education & 0.0060 & 0.0080 & 0.0000 & 0.0144 & 0.0000 \\
\hline Health, social work & 0.0479 & 0.0442 & 0.0196 & 0.0062 & 0.0272 \\
\hline Culture, sports and entertainment & 0.0359 & 0.0402 & 0.0098 & 0.0431 & 0.0136 \\
\hline
\end{tabular}

Different with "Table I", due to no "encouragement" in negative list, the result of it is more of a restriction degree, and the opposite analysis is the industry relative openness degree. It can be found in "Table II" that there is certain difference between the change of the three industries and positive list. Among which, the result of primary industry is similar with table 1, and its restriction degree is gradually increasing; restriction degree of the secondary industry has declined, that is, the openness degree is gradually increasing, except for production and supplication of electricity, thermodynamics, gas and water; in the tertiary industry, the openness degree is increasing, except for transportation, leasing and business service, scientific research, technical services, culture, sports and entertainment. Among which, the restriction degree of hotels, catering, real estate and resident service is zero, which is in accordance with the policy background of development of Free Trade Zone.

TABLE III. RESTRICTION INDEX OF POSITIVE LIST

\begin{tabular}{|c|c|c|c|c|c|c|}
\hline & 2002 & 2004 & 2007 & 2011 & 2015 & 2017 \\
\hline $\begin{array}{l}\text { Agriculture, forestry, animal husbandry and } \\
\text { fishery }\end{array}$ & 0.3478 & 0.3478 & 0.3478 & 0.3478 & 0.2174 & 0.3913 \\
\hline Mining industry & 0.5789 & 0.5789 & 1.0000 & 0.9474 & 0.4737 & 0.3158 \\
\hline Manufacturing industry & 0.3807 & 0.3864 & 0.5227 & 0.4205 & 0.1534 & 0.0682 \\
\hline $\begin{array}{l}\text { Production and supply of electricity, gas and } \\
\text { water }\end{array}$ & 0.4286 & 0.4286 & 0.5714 & 0.7143 & 0.7143 & 0.4286 \\
\hline Construction industry & 0.0000 & 0.0000 & 0.0000 & 0.0000 & 0.0000 & 0.0000 \\
\hline Transportation, warehousing and postal services & 0.6111 & 0.6111 & 0.7222 & 0.7222 & 0.5000 & 0.5000 \\
\hline $\begin{array}{l}\text { Information transmission, computer services and } \\
\text { software }\end{array}$ & 0.0500 & 0.0500 & 0.0500 & 0.0500 & 0.0500 & 0.1500 \\
\hline Wholesale and retail trade & 1.1429 & 1.1429 & 0.8571 & 0.8571 & 0.4286 & 0.7143 \\
\hline Hotels and catering services & 0.0000 & 0.0000 & 0.0000 & 0.0000 & 0.0000 & 0.0000 \\
\hline Financial industry & 0.3333 & 0.3333 & 0.2381 & 0.2381 & 0.1905 & 0.3810 \\
\hline Real estate & 0.4000 & 0.6000 & 0.6000 & 0.6000 & 0.0000 & 0.0000 \\
\hline Leasing and business service & 0.5455 & 0.7273 & 0.4545 & 0.4545 & 0.4545 & 0.2727 \\
\hline $\begin{array}{l}\text { Scientific research, technical services and } \\
\text { geological survey }\end{array}$ & 0.1176 & 0.1176 & 0.2941 & 0.2941 & 0.1765 & 0.3529 \\
\hline $\begin{array}{l}\text { Water conservancy, environment and public } \\
\text { facilities management }\end{array}$ & 0.1667 & 0.1667 & 0.5000 & 0.3333 & 0.2500 & 0.0000 \\
\hline Resident and other service & 0.0000 & 0.0000 & 0.0000 & 0.0000 & 0.0000 & 0.0667 \\
\hline Education industry & 0.6667 & 0.5000 & 0.5000 & 0.5000 & 0.6667 & 0.3333 \\
\hline Health, social security and social welfare & 0.1000 & 0.2000 & 0.1000 & 0.0000 & 0.1000 & 0.1000 \\
\hline Culture, sports and entertainment & 0.3200 & 0.3600 & 0.6800 & 0.6400 & 0.5200 & 0.4400 \\
\hline
\end{tabular}

\section{B. Measurement of Industry Restriction Index}

In order to avoid the subjectivity of the assignment method, we have also measured the degree of restriction in a certain industry by proportion of restrictions and prohibitions in the major industry, in this way, the two foreign investment management mode can be compared and analyzed with the same standard.

It can be seen from "Table III" that the results are not much different from "Table I", that is, limitation degree is in the descending trend and manufacturing restrictions are the 
biggest. Based on the same calculation method, we have measured the restriction degree of negative list management mode, and the results can be seen in "Table IV".

TABLE IV. RESTRICTION INDEX OF NEGATIVE LIST

\begin{tabular}{|c|c|c|c|c|c|}
\hline & 2013 & 2014 & 2015 & 2016 & 2017 \\
\hline Agriculture, forestry, animal husbandry and fishery & 0.3043 & 0.2609 & 0.2609 & 1.0896 & 0.2174 \\
\hline Mining industry & 0.8421 & 0.7368 & 0.4211 & 0.2105 & 0.3158 \\
\hline Manufacturing industry & 0.3352 & 0.2614 & 0.1136 & 0.1818 & 0.0739 \\
\hline Production and supply of electricity, gas and water & 0.7143 & 0.2857 & 0.4286 & 0.5714 & 0.4286 \\
\hline Wholesale and retail trade & 0.2857 & 0.2857 & 0.0000 & 1.5000 & 0.0000 \\
\hline Transportation, warehousing and postal services & 0.7222 & 0.5000 & 0.2222 & 0.9444 & 0.2222 \\
\hline Hotels and catering services & 1.0500 & 0.7500 & 0.9500 & 1.0500 & 0.5000 \\
\hline $\begin{array}{l}\text { Information transmission, software and information } \\
\text { technology services }\end{array}$ & 0.0000 & 0.0000 & 0.0000 & 0.2857 & 0.0000 \\
\hline Financial industry & 0.6667 & 0.6667 & 0.3333 & 0.8333 & 0.3333 \\
\hline Real estate & 0.2381 & 0.1905 & 0.7143 & 0.9048 & 0.6190 \\
\hline Leasing and business service & 0.8000 & 0.6000 & 0.0000 & 0.2000 & 0.0000 \\
\hline Scientific research, technical services & 1.1818 & 0.8182 & 0.8182 & 2.0909 & 0.4545 \\
\hline $\begin{array}{l}\text { Water conservancy, environment and public facilities } \\
\text { management }\end{array}$ & 0.7059 & 0.2353 & 0.2353 & 0.8235 & 0.2353 \\
\hline Resident, repairs and other service & 0.2500 & 0.2500 & 0.2500 & 2.7500 & 0.1667 \\
\hline Education & 0.0000 & 0.0000 & 0.0000 & 0.3333 & 0.0000 \\
\hline Health, social work & 0.5000 & 0.5000 & 0.3333 & 0.3333 & 0.3333 \\
\hline Culture, sports and entertainment & 0.1000 & 0.1000 & 0.1000 & 1.1000 & 0.1000 \\
\hline Agriculture, forestry, animal husbandry and fishery & 0.4800 & 0.3200 & 0.8800 & 0.8800 & 0.8000 \\
\hline
\end{tabular}

The results in "Table IV" is similar to the results in "Table II", in the two tables, descent degree of restriction degree of the three industries, that is, the trend of industry openness degree is the same. Comparing the positive and negative list management mode measured by the four tables, we will find that the positive list management mode of the national level and the negative list management mode of the Free Trade Zone have little difference in the first and second industries, among which, for industries related to sources and national basic economic lifeline, the degree of policy openness and restriction has been preserved. Compared with positive list management code, negative list management mode is more active in the openness degree of the tertiary industry, the service industry, especially residents' service related to basic necessities. In the respect of financial and computer science and technology, the positive list management mode is more encouraging and more open.

\section{CONCLUSION}

This paper analyses the value of Catalogue of Industries for Guiding Foreign Investment (positive list) and the special management measures for foreign investment in Free Trade Zone (negative list) by two means, the results of which both show that there is certain difference of positive and negative list in industry openness degree. Relatively speaking, the openness degree of negative list is more open in manufacturing and tertiary industries and less restrictive.

At present, there are still some respects that need further improvement in the implementation of the negative list, such as the transparency of the negative list needs to be improved. The essence of negative list is the idea of "legal reservation", thus we shall learn the "top-down" enumeration method from the international negative list, gradually elaborating, thoroughly combing and regulating the regulations on foreign investment so that to further improve the transparency of negative list. Besides, it should also be considered how to strengthen the protection of the nonexistent industries in China Due to the principle obeyed by negative list "No prohibition in law", thus in the face of those industries that have not yet appeared in China, we need to add certain protection items in policy making. Finally, in the process of negative list implementation, it shall be considered how the government changes its management thinking. The government shall gradually turn into the management mode of "pre-admission negative list permission management, post-access supervision". Certainly, it will further improve the prevention system by conducting information sharing platform.

\section{REFERENCES}

[1] Allee T, Peinhardt C. Contingent credibility: The impact of investment treaty violations on foreign direct investment [J]. International Organization, 2011, 65(03): 401-432.

[2] Berger A, Busse M, Nunnenkamp P, et al. Do trade and investment agreements lead to more FDI? Accounting for key provisions inside the black box [J]. International Economics and Economic Policy, 2013, 10(2): 247-275.

[3] Busse M, Königer J, Nunnenkamp P. FDI promotion through bilateral investment treaties: more than a bit? $[\mathrm{J}]$. Review of World Economics, 2010, 146(1): 147-177.

[4] Hallward-Driemeier M. Do bilateral investment treaties attract foreign direct investment? only a bit and they could bite $[\mathrm{J}]$. Only a Bit And They Could Bite (June 2003). World Bank Policy Research Working Paper, 2003 (3121).

[5] Yackee J W. Do Bilateral Investment Treaties Promote Foreign Direct Investment-Some Hints from Alternative Evidence [J]. Va. J. Int'l L., 2010, 51: 397.

[6] Deng Juanjuan. Research on the openness and internationalization strategy of China's logistics industry [J]. Study of Commercialeconomy, 2016, 08:93-95. 邓娟娟.我国物流行业对外开放度及国际化战略研究 [J].商业经济研究,2016,08:93-95.

[7] Gong Baihua. Legal principle of "No prohibition in law" and "negative list" mode in Shanghai Free Trade Zone [J]. Oriental Law, 2013,06:137141 龚柏华.“法无禁止即可为”的法理与上海自贸区“负面清单”模式 [J].东方法学,2013,06:137-141. 
[8] Hu Jiaxiang. Analysis on the legal issues of national treatment before international investment access---on the negative list of Shanghai Free Trade Zone [J]. Journal of Shanghai Jiaotong University (philosophy and social science edition), 2014, 01:65-73. 胡加祥. 国际投资准入前国 民待遇法律问题探析一一兼论上海自贸区负面清单 $[\mathrm{J}]$. 上海交通大 学学报(哲学社会科学版),2014,01:65-73.

[9] Pang Mingchuan, Zhu Hua, Liu Jing. Study on the reform of China's foreign investment access system based on pre-establishment national treatment plus negative list management $[\mathrm{J}]$. Macroeconomic study, 2014, 2:12-18+41. 庞明川,朱华,刘婧. 基于准入前国民待遇加负面清 单管理的中国外资准入制度改革研究[J]. 宏观经济研究, 2014,12:12$18+41$.

[10] Shao Haiyan, Lu Jinong, Chen Qingping. Research on the impact of investment liberalization [J]. Finance and Trade Research, 2016, 3:55$62+79$. 邵海燕, 卢进勇, 陈清萍. 投资自由化经济影响研究述评 $[\mathrm{J}]$. 财 贸研究,2016,03:55-62+79.

[11] Sun Yuanxin, Ji Li, Zhou Renyuan. Negative list (2013 edition) and its improvement of Shanghai Free Trade Zone [J]. Foreign Economics and Management, 2014, 3:74-80. 孙元欣,吉莉,周任远.上海自由贸易试验 区负面清单(2013 版)及其改进[J].外国经济与管理,2014,03:74-80.

[12] Sun Yuanxin. International mirror of negative list management of foreign investment: example of Shanghai Free Trade Zone [J]. Reform, 2014, 10: 37-45. 孙元欣.外资负面清单管理的国际镜鉴:上海自贸区 例证[J].改革,2014,10:37-45.

[13] Sun Yuanxin, Xu Chen, Li Jinjin. Assessment and thinking of negative list (2014 edition) on Shanghai Free Trade Zone [J]. Shanghai Economy Review, 2014, 10: 81-88+89. 孙元欣,徐晨,李津津.上海自贸试验区负 面清单(2014 版)的评估与思考[J].上海经济研究,2014,10:81-88+99.

[14] Wu Fang. The industry selection in South Korea's negative list and its enlightenment to China [J]. International Trade, 2014, 06:34-38. 武芳. 韩国负面清单中的产业选择及对我国的启示 [J]. 国际贸 易,2014,06:34-38.

[15] Wang Jing. Influence and countermeasure of "negative list" mode on foreign investment management in China [J]. Management World, 2014, 08: 169-170. 王晶.“负面清单”模式对我国外资管理的影响与对策 [J]. 管理世界,2014,08:169-170.

[16] Wang Xinkui. The key point of China (Shanghai) Free Trade Zone reform: implement "negative list" of foreign investment access [J]. Journal of Shanghai University of International business and economics, 2014, 01:5-11. 王新奎.中国(上海)自贸试验区改革的重点:对外商投 资准入实施“负面清单”管理[J].上海对外经贸大学学报,2014,01:5-11.

[17] Yang Haikun. Interpretation and promotion of the negative list of China (Shanghai) Free Trade Zone [J]. Jianghuai Tribune, 2014, 03: 5-11. 杨 海坤.中国(上海)自由贸易试验区负面清单的解读及其推广 [J].江淮 论坛,2014,03:5-11

[18] Zhang Luqing. Influence of Bilateral Investment Agreements on the attraction of FDI in developing country---based on the empirical research [J]. Finance and Economics, 2009, 09: 26-33. 张鲁青. 双边投 资协定对发展中国家吸引 FDI 的影响一一基于面板数据的实证研 究[J].财经科学,2009,09:26-33.

[19] Zhang Xiaoming, Zhang Jianhua. Reference to the International Experience of "negative list" investment management mode in Shanghai Free Trade Zone [J]. Study of Commercialeconmy, 2015, 02: 35-36. 张 小明,张建华.上海自贸区“负面清单”投资管理模式的国际经验借鉴 [J].商业经济研究,2015,02:35-36. 